\title{
EFFECTS OF NITRITE ON VITAMIN A AND E LEVELS IN THE BLOOD SERUM AND LIVER OF PIGS
}

\author{
M. DVOǨ́K \\ Veterinary Research Institute, 62132 Brno
}

Received December 8, 1983

\begin{abstract}
Dvořák, M.: Effects of Nitrite on Vitamin $A$ and $E$ Levels in the Blood Serum and Liver of Pigs. Acta vet. Brno, 53, 1984: 159-168.

Vitamin A and E levels in the blood serum and, in most cases, also in the liver were determined in 80 weaned piglets or feeder pigs. The aim of one experiment was to study the effects of sodium nitrate and five experiments were designed to assess the effects of sodium nitrite or potassium nitrite, all administered in the drinking water or added to dry complete feed mixtures for 20 to 42 days. In no case (including that of potassium nitrite intake at $1.8 \mathrm{~g}$ per $\mathrm{kg}$ body mass for 28 days) was this supplementation found to exert adverse effects on the metabolism of vitamins A and $\mathrm{E}$. Some indication of a downward trend in vitamin $\mathrm{A}$ and $\mathrm{E}$ levels in the serum and liver was found in four experiments. There were no adverse effects on either health status or gains in body mass. Toxic effects were produced by administration of $31 \mathrm{mg} \mathrm{NO}-1 / \mathrm{kg}^{2}$ body mass in the drinking water. Consideration was also given to the development and course of methaemoglobinaemia.
\end{abstract}

Nitrate, nitrite, axerophtol, tocopherol, methaemoglobin, toxicology.

Nitrate and nitrite pose an increasing problem in the alimentary toxicology of both man and farm animals. Nitrate occurs in plants where its natural content is increased by intensive use of nitrogenous fertilizers. It does not constitute a direct hazard and is normally excreted in the urine. Under certain conditions, however, it can be reduced to nitrite in the alimentary tract and readily absorbed, particularly in ruminants. Nitrite exerts pathophysiological effects (Bartík, Piskač et al. 1974; Fritsch and de Saint-Blanquat 1976) the most important of which is the development of methaemoglobinaemia.

Nitrate and nitrite are also believed to have a depressive effect on vitamin A status of the body and possibly to advance the development of its deficiency in farm animals receiving carotene or vitamin $A$ in amounts regarded as sufficient. In monogastric carotene-fed animals hepatic vitamin A reserves are reduced by nitrate and nitrite, in those fed vitamin A, only by nitrite (Emerick and Olson 1962; L huissier et al. 1976). Administration of nitrite to rats resulted also in a deficiency of vitamin E (O'Dell et al. 1960). Topical implications of this problem emerge from the data on health disorders produced in pigs by a high nitrate content of the feeds (Dobai 1960; Sprenger 1977) and on waters becoming increasingly unsafe because of nitrite and nitrate contamination (Citová 1982). Impairment of vitamin A metabolism is a more serious problem in monogastric animals than in ruminants; a particularly high sensitivity to nitrite is shown by pigs (Wiesner 1978).

The aim of the present study was to find to which extent experimental addition of nitrite to water or feed would affect vitamin $\mathrm{A}$ and $\mathrm{E}$ requirements of young pigs and to assess possible adverse effects of nitrite on their growth and some productivity values. Another objective was to study the development and course of methaemoglobinaemia used here as a measure of nitrite intake. 


\section{Materials and Methods}

Effects of nitrite on vitamin $\mathrm{A}$ and $\mathrm{E}$ levels in the blood serum and liver of pigs were followed in a total of 80 early weaned Large White piglets and feeder pigs including 11 animals used in Experiment I which was designed to assess the effect of nitrate. These substances were added to drinking water in the trough or mixed into complete feed mixtures, namely ČOS 2 (starter), declared to contain $8000 \mathrm{I}$. U. vitamin A and $30 \mathrm{mg}$ vitamin E per $\mathrm{kg}$, or A1 (grower), declared to contain $2000 \mathrm{I}$. U. vitamin A per kg. Control pigs were fed and watered similarly except that they received no nitrite or nitrate supplements. Using various dosage rates and forms of administration to animals of varying ages, seven experiments were conducted which, besides the main objective, followed clinical state and body mass gain and in most cases also the percentage of circulating methaemoglobin (MHb).

Experiment 1 included five feeder pigs with an initial body mass of $22.8 \pm 1.2 \mathrm{~kg}$. They were fed feed mixture $\mathrm{A} 1$ and received a $\mathrm{NaNO}_{3}$ solution in the drinking water for 25 days. The $\mathrm{NaNO}_{3}$ daily dose per group was $8.4 \mathrm{~g}$ during the first 5 days and was then gradually increased up to $50 \mathrm{~g}$. The total amount of $\mathrm{NaNO}_{3}$ administered per animal was $139 \mathrm{~g}$, the daily dose per animal averaging $5.5 \mathrm{~g}$. The effects were compared with the results obtained in a control group of their six littermates having $21.3 \pm 0.7 \mathrm{~kg}$ in body mass at the start of the experiment.

Experiment 2 included five piglets with an initial body mass of $11.5 \pm 1.4 \mathrm{~kg}$, weaned three weeks previously. They were fed feed mixture ČOS 2 and received a $\mathrm{KNO}_{2}$ solution in the drinking water for 28 days. The daily $\mathrm{KNO}_{2}$ dose per group was $1.3 \mathrm{~g}$ during the first 6 days and was then gradually increased to $6.6 \mathrm{~g}$. The total amount of $\mathrm{KNO}_{2}$ administered per animal was $16.9 \mathrm{~g}$, the daily dose per animal averaging $0.6 \mathrm{~g}$. The effects were compared with the results obtained in a group of their six littermates having $11.1 \pm 1.4 \mathrm{~kg}$ in body mass at the start of the experiment.

Experiment 3 included four feeder pigs with an initial body mass of 25.0 (21.8 to 27.8$) \mathrm{kg}$. They were fed $\mathrm{A} 1$ and received $\mathrm{NaNO}_{2}$ in the drinking water. The $\mathrm{NaNO}_{2}$ daily dose per group was $2.64 \mathrm{~g}$ during the first 5 days and then was gradually increased to $15.8 \mathrm{~g}$. The total amount of $\mathrm{NaNO}_{2}$ administered per animal during 34 days was $67.3 \mathrm{~g}$, the daily dose per animal averaging $1.98 \mathrm{~g}$. The effects were compared with the results obtained in a control group of their three littermates with an initial body mass of 23.9 (20 to 25.9$) \mathrm{kg}$.

Experiment 4 included thirteen piglets of four litters with an initial body mass of $7.6 \pm 0.4 \mathrm{~kg}$. After being weaned, on average, at 28 days of age, they were fed COS 2 to which $\mathrm{KNO}_{2}$ was added at the rate of $1 \mathrm{~g} / \mathrm{kg}, 2 \mathrm{~g} / \mathrm{kg}$ and $3 \mathrm{~g} / \mathrm{kg}$ in 4,5 and 4 of the 13 piglets, respectively. The results obtained after $\mathrm{KNO}_{2}$ feeding for 28 days were compared with those recorded for the corresponding numbers of their littermates with an initial body mass of $7.6 \pm 0.3 \mathrm{~kg}$.

Experiment 5 included nine feeder pigs with an initial body mass of $22.7 \pm 1.4 \mathrm{~kg}$. They were fed $\mathrm{A} 1$ and received a $\mathrm{KNO}_{2}$ solution in the drinking water for 20 days in increasing doses. The $\mathrm{KNO}_{2}$ dose per animal per day was $1.7 \mathrm{~g}$ during the first 6 days, $2.5 \mathrm{~g}$ during the next 8 days and $3.3 \mathrm{~g}$ during the last 6 days. The total amount of $\mathrm{KNO}_{2}$ administered per animal was $50 \mathrm{~g}$, the daily dose per animal averaging $2.5 \mathrm{~g}$. The effects were compared with those obtained in a control group of their 9 littermates having $21.8 \pm 1.9 \mathrm{~kg}$ in body mass at the start of the experiment.

Experiment 6 included two feeder pigs having 17.5 and $20.0 \mathrm{~kg}$ in body mass at the start of the experiment. They were fed A 1 supplemented with $\mathrm{KNO}_{2}$ at $1 \mathrm{~g} / \mathrm{kg}$ for 42 days. The initial body mass of two control was 15.0 and $22.5 \mathrm{~kg}$. Both groups were examined at weekly intervals. Beginning the 3rd week of the experiment each piglet of the two groups was given $1 \mathrm{~kg}$ feed supplemented with 1, 1.5, 2.5 or $3.7 \mathrm{~g} \mathrm{KNO}_{3}$ once a week in the morning and then deprived of food for the next 24 hours. Blood samples were taken before and 3, 6 and 24 hours after feeding.

In Experiment 7 three weaned piglets, 12 to $14 \mathrm{~kg}$ in body mass, were injected with 1.5 to $4.0 \mathrm{ml}$ of $2 \% \mathrm{NaNO}_{2}$ solution into the ear vein and examined repeatedly for their $\mathrm{MHb}$ levels.

All experimental treatments, blood collections from the cranial vena cava and weighings were conducted between 8 and 9 hours in the morning without previous food deprivation, unless otherwise specified. All animals were deprived of food one day before slaughter. Vitamin A and E levels in the blood plasma were determined fluorometrically according to Thompson et al. (1973) at intervals specified in Results. In slaughtered pigs, hepatic vitamin A and E content was determined according to Thompson et al. (1971) after previous saponification (S en yk et al. 1975). Methaemoglobin in the blood was determined according to a biochemical method based on the formation of cyanmethaemoglobin (Starý et al. 1979). The results are presented as arithmetic means \pm \pm standard errors of the means. The significance of the differences of the means was assessed by Student's $t$-test. 


\section{Results}

The intake of sodium nitrate in Experiment 1 affected neither the health status nor thriftiness of the pigs. During the 25 days of $\mathrm{NaNO}_{3}$ administration their body mass increased by $10.4 \pm 1.4 \mathrm{~kg}$, reaching $33.2 \pm 2.5 \mathrm{~kg}$; that of the control group increased by $9.0 \pm 0.5 \mathrm{~kg}$, amounting to $30.3 \pm 1.1 \mathrm{~kg}$. Based upon the final body mass, the intake of $\mathrm{NaNO}_{3}$ for the whole experimental period was $4.2 \mathrm{~g}$, i. e. $3.06 \mathrm{~g}$ nitrate $\left(\mathrm{NO}_{3}^{-}\right)$per $\mathrm{kg}$ body mass. There were no adverse effects on vitamin $\mathrm{A}$ and $\mathrm{E}$ levels either in the serum or in the liver. At the start of the experiment serum vitamin A concentration was high in consequence of previous ČOS 2 feeding, the value for the controls being $0.15 \mu \mathrm{mol} .1^{-1}$ higher than that found in the experimental group. When determined then at weekly intervals, it showed a gradual decrease with the difference between the two groups diminishing. The final levels in the experimental and control animals were $0.89 \pm$ \pm 0.05 and $0.96 \pm 0.03 \mu \mathrm{mol} .1^{-1}$, respectively. Serum vitamin E concentration, on the other hand, was invariably somewhat higher in the experimetal pigs; the values recorded by the end of the 25-day period for the two groups were $2.23 \pm$ \pm 0.07 and $2.22 \pm 0.06 \mu \mathrm{mol} .1^{-1}$. No significant differences between the groups were found in their hepatic vitamin A and E levels, either (Table 1); total hepatic vitamin A content was $7 \mathrm{mg}$ larger in experimental animals than in the controls.

In Experiment 2 the intake of $\mathrm{KNO}_{2}$ by piglets during the 28-day period, based upon the final body mass of $23.7 \pm 2.5 \mathrm{~kg}$, was $713 \mathrm{mg}$, i. e. $335 \mathrm{mg}$ nitrite $\left(\mathrm{NO}_{2}^{-}\right)$ per $\mathrm{kg}$ body mass. No health disorders were observed. Control piglets gained nonsignificantly less and reached a body mass of $22.1 \pm 2.1 \mathrm{~kg}$. Their serum vitamin $\mathrm{A}$ and $\mathrm{E}$ levels were invariably somewhat lower than those of the experimental animals from the start of the experiment. The values recorded for the con-

Table 1

Plan of experiments on nitrate or nitrite administration to pigs and the results of their liver examination

\begin{tabular}{|c|c|c|c|c|c|c|c|c|}
\hline $\begin{array}{c}\text { Experi- } \\
\text { ment } \\
\text { No. }\end{array}$ & $\begin{array}{c}\text { a) } \\
\text { No. } \\
\text { animals }\end{array}$ & Supplement & $\begin{array}{l}\text { Experi- } \\
\text { mental } \\
\text { period } \\
\text { (days) }\end{array}$ & $\begin{array}{l}\text { b) } \\
\text { Daily } \\
\text { dose } \\
(\mathrm{g})\end{array}$ & $\begin{array}{c}\mathrm{c}) \\
\text { Total } \\
\text { dose } \\
\left(\mathrm{mg} \cdot \mathrm{kg}^{-1}\right)\end{array}$ & $\begin{array}{l}\text { d) } \\
\text { Body mass } \\
(\mathrm{kg})\end{array}$ & \multicolumn{2}{|c|}{$\begin{array}{l}\text { Llver concentration of } \\
\text { vitamin A vitamin E } \\
\left(\mu \mathrm{mol} . \mathrm{kg}^{-1}\right)\end{array}$} \\
\hline 1 & $\begin{array}{l}5(3) \\
6(3)\end{array}$ & $\mathrm{NaNO}_{3}$ with water & 25 & 5.5 & 4200 & $\begin{array}{l}33.2 \pm 2.5 \\
30.3 \pm 1.1\end{array}$ & $\begin{array}{l}188 \pm 8 \\
175 \pm 5\end{array}$ & $\begin{array}{l}3.94 \pm 1.16 \\
5.10 \pm 0.84\end{array}$ \\
\hline 2 & $\begin{array}{l}5(1) \\
6(2)\end{array}$ & $\mathrm{KNO}_{2}$ with water & 28 & 0.6 & 713 & $\begin{array}{l}23.7 \pm 2.5 \\
22.1 \pm 2.1\end{array}$ & $\begin{array}{l}268 \\
268\end{array}$ & $\begin{array}{l}4.87 \\
5.10\end{array}$ \\
\hline 3 & $\begin{array}{l}4(4) \\
3(3)\end{array}$ & $\mathrm{NaNO}_{2}$ with water & 34 & 1.98 & 1633 & $\begin{array}{l}41.2 \pm 3.1 \\
37.7 \pm 2.9\end{array}$ & $\begin{array}{l}222 \pm 26 \\
227 \pm 10\end{array}$ & $\begin{array}{l}7.49 \pm 1.04 \\
6.33 \pm 0.78\end{array}$ \\
\hline 4 & $\begin{array}{l}13(8) \\
13(8)\end{array}$ & $\mathrm{KNO}$, with starter & 28 & 1.14 & 1828 & $\begin{array}{l}17.4 \pm 1.3 \\
16.2 \pm 0.7\end{array}$ & $\begin{array}{l}245 \pm 20 \\
249 \pm 26\end{array}$ & $\begin{array}{l}5.92 \pm 0.67 \\
7.35 \pm 0.81\end{array}$ \\
\hline 5 & $\begin{array}{l}9(5) \\
9(5)\end{array}$ & $\mathrm{KNO}_{2}$ with water & 20 & 2.50 & 1458 & $\begin{array}{l}34.3 \pm 1.7 \\
33.3 \pm 2.7\end{array}$ & $\begin{array}{l}272 \pm 25 \\
281 \pm 10\end{array}$ & $\begin{array}{l}5.85 \pm 0.93 \\
5.89 \pm 0.72\end{array}$ \\
\hline 6 & $\begin{array}{l}2(2) \\
2(2)\end{array}$ & $\begin{array}{l}\mathrm{KNO}_{2} \text { with grower } \\
\mathrm{KNO}_{2} \text { once a week }\end{array}$ & 42 & $\begin{array}{l}1.43 \\
0.21\end{array}$ & $\begin{array}{r}1806 \\
242\end{array}$ & $\begin{array}{l}32.5 \\
36.0\end{array}$ & $\begin{array}{l}179 \\
181\end{array}$ & $\begin{array}{l}5.70 \\
6.10\end{array}$ \\
\hline
\end{tabular}

a) Figures in parentheses are the numbers of liver examinations.

b) Mean daily dose per animal.

c) Total intake per $\mathrm{kg}$ body mass.

d) Body mass at the end of the experiment. 
trols at the end of the experiment where $0.88 \pm 0.04$ and $1.79 \pm 0.19 \mu \mathrm{mol} .1^{-1}$ as against $1.03 \pm 0.07$ and $1.87 \pm 0.23 \mu \mathrm{mol} .1^{-1}$ in the experimental animals. The differences were not significant. Hepatic vitamin A and E concentrations also did not show any significant differences between the groups (Table 1).

Experiment 3 piglets receiving $\mathrm{NaNO}_{2}$ in the drinking water showed no clinical signs of intoxication up to the 33rd day, but some unpalatability of the water supplemented with the higher nitrite doses was observed. Body mass gain during the first 27 days was $15.75 \mathrm{~kg}$ in the experimental animals and $13.18 \mathrm{~kg}$ in the controls. The proportions of $\mathrm{MHb}$ in the blood of experimental pigs were invariably high: $13.7 \%$ on day $15,24.3 \%$ on day 29 and $4.6 \%$ on day 30 after one-day food deprivation; the values recorded on the same day in the controls were 4.5, 3.3 and $1.6 \%$. Serum vitamin A and E levels showed practically no differences between the groups at the start of the experiment. From the 15th day onwards vitamin A level was invariably somewhat lower and vitamin $\mathrm{E}$ level somewhat higher in animals receiving $\mathrm{NaNO}_{2}$. The differences were largest on day 15 , with the values for vitamin $\mathrm{A}$ being 0.76 and $0.85 \mu \mathrm{mol} . \mathrm{1}^{-1}$ and those for vitamin E 1.76 and $1.46 \mu \mathrm{mol} .1^{-1}$ but decreased during the subsequent days. After the first morning one-half of the largest dose of $\mathrm{NaNO}_{2}\left(7.9 \mathrm{~g} \mathrm{NaNO}_{2}\right.$ per group, i. e. $47 \mathrm{mg} \mathrm{NaNO}$ or $31 \mathrm{mg} \mathrm{NO}-$ per $\mathrm{kg}$ body mass) on day 34 the two heaviest pigs died quite suddenly. Their musculature was pink and the lungs and blood were brownish in colour, the kidneys were congested and the liver of one of them was enlarged. Blood samples collected from the thorax of these two piglets at necropsy contained 49 and $35 \% \mathrm{MHb}$. On subsequent days the morning and the afternoon nitrite doses in the drinking water for the remaining animals were each reduced to $23 \mathrm{mg} \mathrm{NO}_{2}^{-}$per kg body mass and all the remaining animals were slaughtered on the 38th of the experiment. One day previously $\mathrm{MHb}$ proportions in the blood of experimental and control piglets averaged $13 \%$ and $1.9 \%$, respectively. Slightly lower vitamin A levels and higher vitamin E levels in the blood serum of experimental pigs as compared with control continued till slaughter. Hepatic vitamin $A$ and $E$ reserves were unaffected by the nitrite intake (Table 1) even in the pigs that died. During the 34-day period the experimental group consumed $1633 \mathrm{mg} \mathrm{NaNO}$, i. e. $1099 \mathrm{mg} \mathrm{NO}-$, per kg body mass.

In Experiment 4 thirteen experimental early weaned piglets consumed a total of $210 \mathrm{~kg}$ ČOS supplemented with $415 \mathrm{~g} \mathrm{KNO}_{2}$ during 28 days, i. e. an average of $0.57 \mathrm{~kg}$ C̆OS with $1.14 \mathrm{~g} \mathrm{KNO}_{2}$ per animal per day. Feed consumption by 13 controls during the same period was lower, $0.53 \mathrm{~kg}$ per animal per day. Nitrite-fed pigs were thriftier: their average daily gain was $350 \mathrm{~g}$ and the efficiency

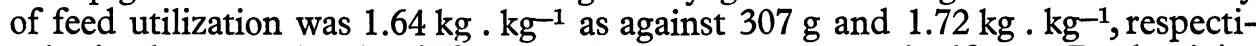
vely, in the controls; the differences, however, were not significant. Productivity values were better in experimental piglets of all litters irrespective of whether the $\mathrm{KNO}_{2}$ supplement was 1,2 or $3 \mathrm{~g}$ per $\mathrm{kg}$ feed. Therefore the experiment was evaluated as a whole. The mean $\mathrm{KNO}_{2}$ supplement per piglet for the experimental period was calculated to be $31.9 \mathrm{~g}$. The mean intake of $\mathrm{KNO}_{2}$ during the 28-day period was $1828 \mathrm{mg}$, i. e. $987 \mathrm{mg} \mathrm{NO}-$, per $\mathrm{kg}$ final body mass $(17.45 \pm$ $\pm 1.3 \mathrm{~kg}$ ). The quantities of $\mathrm{KNO}_{2}$ consumed by piglets fed 1,2 and $3 \mathrm{~g} \mathrm{KN \textrm {K } _ { 2 }}$ per $\mathrm{kg}$ feed were $1.85,3.11$ and $4.65 \mathrm{~g} \mathrm{KNO}_{2}$ per $\mathrm{kg}$ gain. Total gain was $9.8 \pm$ $\pm 0.9 \mathrm{~kg}$ in the experimental group and $11.1 \mathrm{~kg}$ in piglets fed the largest $\mathrm{KNO}_{2}$ supplement. In the control group, total gain was $8.6 \pm 0.6 \mathrm{~kg}$, while that of sibs to the experimental piglets fed the largest $\mathrm{KNO}_{2}$ supplement was $8.7 \mathrm{~kg}$. $\mathrm{MHb}$ levels in the blood serum of nitrite-fed piglets were significantly affected, reaching 
a peak of $10.2 \pm 1.3 \%$ on day 28 (Fig. 1). Marked differences, however, were observed at the different $\mathrm{KNO}_{2}$ dosage levels. The mean peak $\mathrm{MHb}$ values obtained at 1,2 and $3 \mathrm{~g} \mathrm{KNO}_{2}$ per $\mathrm{kg}$ feed were $5.5 \%$ on day $28,12.3 \%$ on day 28 and $18.4 \%$ on day 14 , respectively. The maximum individual value was $21.4 \%$ $M H b$. After the 24-hour food deprivation before slaughter the $M H b$ level fell to $2.6 \pm 0.2 \%$ and was no longer different from that found in the controls.
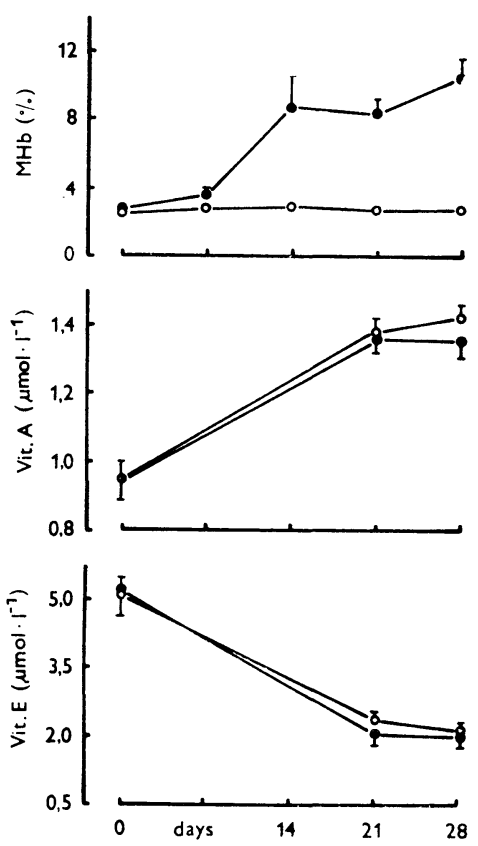

Fig. 1. Blood methaemoglobin and blood serum vitamin $A$ and $E$ levels of early weaned piglets fed ČOS, a commercial starter, without (open circles) and with potassium nitrite supplements (closed circles).

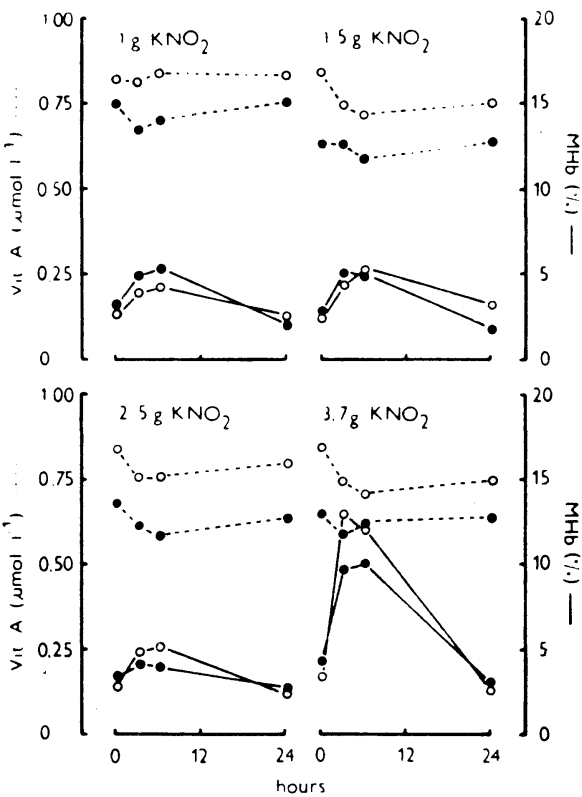

Fig. 2. Blood serum vitamin $A$ and blood methaemoglobin levels of two groups of feeder pigs which were both given 1.0 to $3.7 \mathrm{~g}$ potassium nitrite per animal with morning feed once a week and deprived op food for the next 24 hours, but one of the two groups was in addition on regular $\mathrm{KNO}_{2}$ supply (closed circles) and the other was not (open circles).

Blood serum vitamin $\mathrm{A}$ and $\mathrm{E}$ concentrations were practically unaffected by the different $\mathrm{KNO}_{2}$ intakes. Vitamin A level rose invariably, as in the controls, and vitamin $\mathrm{E}$ level showed a decline (Fig. 1). A small difference in vitamin A levels in favour of the controls was observed on day 28, but was not significant. The somewhat lower content of vitamins $\mathrm{A}$ and $\mathrm{E}$ in the liver of experimental piglets was not significant, either (Table 1). Total hepatic vitamin A content was $2 \mathrm{mg}$ lower than in the controls.

In Experiment 5 the administration of $\mathrm{KNO}_{2}$ to feeder pigs affected neither their health nor thriftiness. By the end of the 20-day experimental period their body mass had risen by $11.6 \pm 0.8 \mathrm{~kg}$, reaching $34.3 \pm 1.7 \mathrm{~kg}$. Control animals gained $11.5 \pm 0.8 \mathrm{~kg}$ and their body mass at the end of the experiment was $33.3 \pm$ $\pm 2.7 \mathrm{~kg}$. Based on final body mass, the intake of $\mathrm{KNO}_{2}$ for the whole experimental period was $1458 \mathrm{mg}$, i. e. $787 \mathrm{mg} \mathrm{NO}_{2}^{-}$, per $\mathrm{kg}$ body mass. One-half of the 
largest daily dose of $\mathrm{KNO}_{2}$ in the last days of the experiment was $48 \mathrm{mg}$, i. e. $26 \mathrm{mg} \mathrm{NO}$, per kg body mass.

$M H b$ levels at the start of the experiment and on days 6,15,20 and 21 (at slaughter after 24-hour food deprivation) were $2.8,8.1,16.1,14.9$ and $3.2 \%$, respectively. There were considerable inter-subject differences, the maximum value of $28 \%$ being recorded on days 15 and 20 in the pig with the largest gain in body mass. In the control group, MHb levels fluctuated between 1.9 and $4.8 \%$. Blood serum vitamin $\mathrm{A}$ and $\mathrm{E}$ concentrations showed practically no difference between the groups at the start of the experiment; on day 20 they showed a slight decrease in the experimental group, declining to $0.96 \pm 0.04$ and $2.32 \pm 0.14$ $\mu \mathrm{mol} .1^{-1}$, as against $0.99 \pm 0.04$ and $2.40 \pm 0.18 \mu \mathrm{mol}^{-1}{ }^{-1}$ respectively, in the control group. Difference in the hepatic concentrations of these vitamins were not significant, either (Table 1). Total hepatic vitamin A and E content in the experimental group was $8 \mathrm{mg}$ and $0.17 \mathrm{mg}$ lower than in the controls.

In Experiment 6, feeder pigs receiving $\mathrm{KNO}_{2}$ with feed for 41 days had a mean gain of $14 \mathrm{~kg}$ as against that of $17 \mathrm{~kg}$ in the controls. The slower growth of experimental piglets, which became apparent very soon, was accompanied later by reduced readiness to eat the nitrite-supplemented feed mixture $A 1$, the consumption of which decreased by almost $0.3 \mathrm{~kg}$ per animal per day. Feed consumption per $\mathrm{kg}$ gain was $3.63 \mathrm{~kg}$ as against $3.19 \mathrm{~kg}$ in the controls. MHb levels showed at first practically no differences between the groups at morning measurements; starting the 3rd week they became 0.1 to $0.8 \%$ higher in the experimental group, but only exceptionnally reached $4 \%$. Blood serum vitamin A concentration was at first $0.11 \mu \mathrm{mol} .1^{-1}$ higher in the control group; by the end of the experiment this difference in the morning levels has risen to $0.19 \mu \mathrm{mol} .1^{-1}$, the final serum vitamin A levels being $0.65 \mu \mathrm{mol} .1^{-1}$ in the experimental group and $0.84 \mu \mathrm{mol} .1^{-1}$ in the controls (Fig. 2). Serum vitamin $\mathrm{E}$ level showed fluctuation at morning measurements; the values recorded at the end of the experiment were $3.36 \mu \mathrm{mol}$. $.1^{-1}$ in the experimental group and $3.91 \mu \mathrm{mol} .1^{-1}$ in the controls.

The intake of feed with graded $\mathrm{KNO}_{2}$ supplements given to both groups once a week produced marked changes only after the largest dose of $3.7 \mathrm{~g} \mathrm{KNO}_{2}$. The highest $\mathrm{MHb}$ level, $13 \%$, was found in the control group (Fig. 2). Even at the lower $\mathrm{KNO}_{2}$ doses, $\mathrm{MHb}$ level peaked 3 to 6 hours after feeding and by the end of 24 hours was generally lower than at the beginning of the test. Serum vitamin A concentration showed a similar transient decrease concurrently in

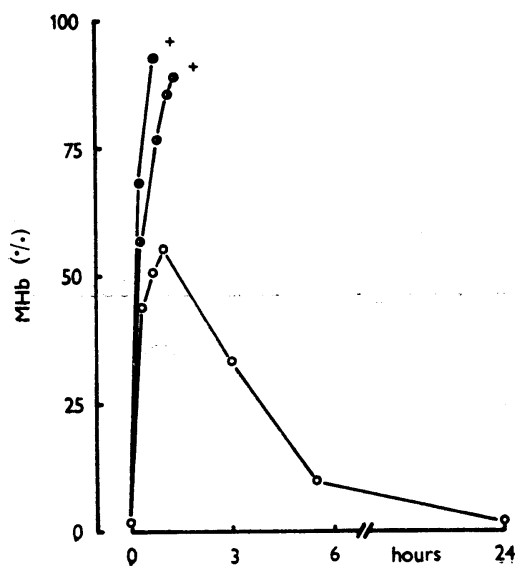
both groups (Fig. 2), a contributory factor to which was apparently the existence of stressful situations associated with blood collections and later with food deprivation. Serum vitamin E concentration, too, showed generally a decrease, occasionally preceded or followed by a rise, and bore no distinct relation to either $\mathrm{KNO}_{2}$ dose or $\mathrm{MHb}$ level.

Fig. 3. Blood methaemoglobin levels of three piglets after intravenous injection of sodium nitrite at $25 \mathrm{mg}$ (open circles), $38 \mathrm{mg}$ (semi-closed circles) and $57 \mathrm{mg}$ (closed circles) per kg body mass. Cross indicates exitus, 
Hepatic vitamin $\mathrm{A}$ and $\mathrm{E}$ concentration was negligibly lower in the experimental piglets than in the controls (Table 1) and there was no substantial difference between the groups in total liver content of these vitamins, either: its values for vitamin $\mathrm{A}$ and $\mathrm{E}$, respectively, averaged $32 \mathrm{mg}$ and $1.5 \mathrm{mg}$ in the experimental group and $36 \mathrm{mg}$ and $1.7 \mathrm{mg}$ in the controls.

In experiment 7 , an abrupt rise in $\mathrm{MHb}$ levels was demonstrated after intravenous administration of $\mathrm{NaNO}_{2}$ solution (Fig. 3). The piglet, weighing $14 \mathrm{~kg}$, that was injected at the rate of $57 \mathrm{mg} / \mathrm{kg}$ body mass died after 43 minutes, with its $\mathrm{MHb}$ value reaching $93 \%$. Another piglet, weighing $13 \mathrm{~kg}$, that was injected with $38 \mathrm{mg} / \mathrm{kg}$ body mass died after 80 minutes and its $\mathrm{MHb}$ value was $88 \%$. In both of them the injection of $\mathrm{NaNO}_{2}$ produced a rapid onset of progressive cyanosis, recumbency, laboured breathing, intermittent tremors and eventually respiratory failure. Necropsy findings were characterized by a brown colour of the blood and of all highly vascularized organs.

The third piglet of the group, weighing $12 \mathrm{~kg}$, that was injected with $25 \mathrm{mg}$ $\mathrm{NaNO}_{2} / \mathrm{kg}$ body mass survived. It developed a lighter degree of cyanosis and also became recumbent but had no marked respiratory distress and the skin resumed its normal pink colour in three hours. MHb level exceeded $50 \%$ at 40 minutes, declined by more than a third by the end of three hours and was within normal limits 24 hours after $\mathrm{NaNO}_{2}$ injection (Fig. 3).

\section{Discussion}

The changes found in blood serum vitamin $\mathrm{A}$ and $\mathrm{E}$ concentration in the present experiments were, in agreement with previous observations (Dvořák and Herzig 1982), apparently related mainly to its alimentary intake as regards vitamin $\mathrm{A}$ and to the age of animals as regards vitamin $\mathrm{E}$. Under the specified conditions, the intake of neither nitrate nor nitrite exerted an unequivocally adverse effect on serum or hepatic levels of the two vitamins. Neither liver vitamin $\mathrm{A}$ and $\mathrm{E}$ content showed any significant differences between the experimental and control animals. However, some indication of a downward trend in vitamin $\mathrm{A}$ and $\mathrm{E}$ levels was observed in four experiments. The possibility cannot be excluded that under conditions of long-term nitrite intake this trend might become more pronounced. However, doses as high as those used in our experiments would be most unlikely to occur under field conditions. On the other hand, it should be remembered that routinely used feeds may contain large amounts of nitrate and that the conditions of its transformation to toxic nitrite in the body of pigs are not well understood. In studies by other workers only nitrite was found to reduce hepatic vitamin A stores in animals supplied directly with vitamin A (O'Dell et al. 1960; Emerick and Ols on 1962; L huissier et al. 1976). The results reported in our study are at variance with the aforementioned data but are not isolated findings. Administration of sodium nitrite to rats at $0.3 \mathrm{~g}$ per 1 water for as long as 6 months had no significant effect on their hepatic vitamin A reserves (Lhuissier and Vernevant 1978). Similarly, its intake by pigs for 105 days, which caused a slight increase in MHb, did not exert adverse effect on their liver vitamin A content (Seerley et al. 1965).

It appears likely that a proportion of the swine population ingests not only nitrate but also nitrite with feed or water. A concentration of $2 \mathrm{mg} \mathrm{NO}_{2}^{-}$per 1 water (Citová 1982), e. g., does not pose any intoxication hazard. In our experiments oral intake of $\mathrm{NaNO}_{2}$ with water caused death of $50 \%$ of the experimental 
feeder pigs only when it was given at a rate as high as $31 \mathrm{mg} \mathrm{NO}_{2}^{-}$per $\mathrm{kg}$ body mass, whereas animals receiving $26 \mathrm{mg} \mathrm{NO}_{2}^{-}$per kg body mass showed no clinical signs of intoxication. Apparently, age-dependent and inter-subject differences in the sensitivity of pigs to nitrite intoxication should be taken into account. The $\mathrm{LD}_{50}$ for rats on oral application is $67 \mathrm{mg} \mathrm{NO}-$ per $\mathrm{kg}$ body mass (Cazottes et al. 1981). However, there are great inter-species differences. Swine are considered more sensitive to nitrate than ruminants (Wiesner 1978; Kühnert 1981). In the light of the observations reported here, not even a relatively high intake of nitrites justifies additional supplementation with vitamins A and E. A less favourable situation, however, may arise even after ingestion of nitrate in fattening pigs which in our country are fed feed mixture SOL (finisher) which, instead of vitamin A supplements, contains carotene in the form of dried forage.

An increase in $\mathrm{MHb}$ in the circulating blood of pigs indicates the operation of nitrite but is not a reliable quantitative criterion of its intake unless a certain quantity of nitrite has been ingested during a short period of time. Even in pigs weighing $32 \mathrm{~kg}$ and consuming $3.7 \mathrm{~g} \mathrm{KNO}_{2}$ with feed, i. e. $62 \mathrm{mg} \mathrm{NO}-\overline{2}$ per kg body mass, $\mathrm{MHb}$ value rose to only $13 \%$. Apparently more hazard arises from the intake with water where nitrite can reach the blood stream more readily and reverse transformation of $\mathrm{MHb}$ to $\mathrm{Hb}$ is not sufficient. The experiment with intravenous injection of $\mathrm{NaNO}_{2}$ showed quite convincingly the ability of young pigs to bring methaemoglobinaemia under control within a relatively short period of time.

The growth of pigs in our study was unaffected by administration of either nitrate or nitrite under the specified conditions. Only upon administration of large nitrite doses to feeder pigs the consumption of the nitrite-supplemented feed or water was occasionally reduced. Surprisingly greater gains in experimental animals than in the controls were found in weaned piglets even at a relatively high level of nitrite supplementation. In rats given nitrite-supplemented feed, marked effects on growth and feed utilization were not observed and anaemia was not produced until the nitrite content of the feed was increased to $1 \%$ (Cazottes et al. 1981). Their feed consumption was reduced when $\mathrm{NO}_{2}^{-}$was fed at the rate of $0.5 \%$ (Fritsch et al. 1983).

Our results suggest that the intake of nitrate or nitrite with water or feed by pigs is not a point of concern with regard to either productivity values or animal health characteristics and does not pose an intoxication hazard provided that it does not exceed $25 \mathrm{mg} \mathrm{NO}_{2}$ per $\mathrm{kg}$ body mass. This, however, does not imply that the question should be dismissed altogether as unimportant. In older pigs adverse effects have been described (Dobai 1960; Sprenger 1977). Moreover, there are veterinary public health regulations and standards which must observed. Considering the unimpaired growth of pigs in our study there is little, if any, justification for $\mathrm{MHb}$ determination to be included among the metabolic test methods for detection of the causes of unthriftiness in weaned piglets and feeder pigs.

\section{Působení dusitanů na hladiny vitamínu A a $\mathrm{E}$ v krevním séru a v játrech prasat}

Hladiny vitamínů $\mathrm{A}$ a $\mathrm{E} v$ krevním séru a většinou též $\mathrm{v}$ játrech byly stanoveny u 80 odstavených selat a rostoucích prasat. $V$ jednom pokusu byl zjištován účinek dusičnanu sodného, v 5 dalších účinky dusitanu sodného nebo draselného při 
podávání v pitné vodě nebo v suché kompletní krmné směsi po dobu $20-42$ dní. V žádném př́padě, ani při prŕímu až $1,8 \mathrm{~g}$ dusitanu draselného na kilogram tělesné hmotnosti za 28 dní nebyl prokázán negativní účinek na metabolismus vitamínu A a E. Určitý trend ke snížení jejich hladin v séru a v játrech byl ve čtyřech pokusech naznačen. Nebyly zjištěny nepříznivé důsledky na zdravotní stav ani na prírůstky tělesné hmotnosti. Toxické účinky se projevily po př́ijmu $31 \mathrm{mg}$ $\mathrm{NO}_{2}^{-} \mathrm{s}$ pitnou vodou na kilogram tělesné hmotnosti. Byly sledovány též podmínky vzniku a průběhu methemoglobinémie.

\section{Воздействие нигритов на уровни витаминов $\mathrm{A}$ и $\mathrm{E}$ в кровяной сыворотке и печени свиней}

Уровни витаминов $\mathrm{A}$ и $\mathrm{E}$ в кровяной сыворотке и в большинстве случаев также в печени были установлены у 80 отьемных поросят и растущих свиней. В ходе одного эксперимента проводились исследования воздействия нитрата натрия, в последующих пяти опытах - нитрита натрия или калия, подаваемых в питьевой воде или в сухой комплектной кормовой смеси в течение 20-42 суток. Ни в одном случае, даже при подаче 1,8 г нитрига калия на килограмм массы тела в течение 28 суток не было установленю отрицателнього воздействия на метаболизм витаминов А и Е. В четырех экспериментах намечалась определенная тенденция на понижение их уровней в сыворотке и печени. Не было установлено неблагоприятных последствий в состоянии здоровья, ни в приросте массы тела. Токсическое воздействие проявилось после приема $31 \mathrm{мг} \mathrm{NO}_{2}^{-}$с питьевой водой на килограмм массы тела. Проводились также исследования условий возникновения и протекания меггемоглобинемии.

\section{References}

BARTÍK, M. - PISKAČ, A. aj.: Veterinární toxikologie. Praha, SZN 1974, 304 p.

CAZOTTES, C. - FRITSCH, P. - GAS, N. - De SAINT-BLANQUAT, G.: Nitrates et nitrites: impacts nutritionnels chez le rat. Ann. Nutr. Metab., 25, 1981: 182-193.

CITOVÁ, D.: Kvalita napáiecích vod olomouckého okresu. Veterinářství, 32, 1982: 231.

DOBAI, S.: Beobachtungen und experimentelle Untersuchungen an Schweinen im Zusammenhang mit der Methämoglobinämie. Acta vet. hung., 10, 1960: 169-182.

DVOŘ́́K, M. - HERZIG, I.: Závislost koncentrace vitamínu A a E v krevní plazmě rostoucích prasat na výživě a na věku. Vet. Med., Praha, 27, 1982: 665-679.

EMMERICK, R. J. - OLSON, O. E.: Effect of nitrate and nitrite on vitamin A storage in the rat. J. Nutr., 78, 1962: 73-77.

FRITSCH, P. - CANAL, M. TH. - de SAINT-BLANQUAT, G.: Expérience en pair-feeding chez des rats traités au nitrate ou au nitrite de sodium. Ann. Nutr. Metab., 27, 1983: 38-47.

FRITSCH, P. - de SAINT-BLANQUAT, G.: Formation des nitrites a partir des nitrates dans le tube digestif. Annls Nutr. Aliment., 30, 1976: 793-804.

KÜHNERT, M.: Neuere Erkenntnisse der Nitrat/Nitrit - und der Ammoniak-Vergiftung bei Wiederkäuern. Mh. VetMed., 36, 1981: 34-36.

LHUISSIER, $M$. - SUSCHETET, M. - CAUSERET, J.: Influence des nitrites et des nitrates sur certains aspects de l'état de nutrition vitaminique. Annls Nutr. Aliment., 30, 1976: 847-851.

LHUISSIER, M. - VERNEVAUT, M.-F.: Effets du nitrite de sodium sur les concentration en diverses vitamines de tissus de rat. J. internat. Vitaminol. Nutr., 48, 1978: 79-83.

O'DELL, B. L. - EREK, Z. - FLYNN, L. - GARNER, G. B. - MUHRER, M. E.: Effects on nitrite containing rations in producing vitamin $\mathrm{A}$ and vitamin $\mathrm{E}$ deficiencies in rats. J. Anim. Sci., 19, 1960: 1280.

SEERLEY, R. W. - EMERICK, R. J. - EMBRY, L. B. - OLSON, O. E.: Effect of nitrate or nitrite administered continuously in drinking water for swine and sheep. J. Anim. Sci., 24, 1965: $1014-1019$. 
SENYK, G. F. - GREGORY, J. F. - SHIPE, W. F.: Modified fluorometric determination of vitamin A in milk. J. Dairy Sci., 58, 1975: 558 - 560.

SPRENGER, H.: Erfordernisse und Erfahrungen zur Fütterung auf Gesundheit und Fruchtbarkeit in der Rinder - und Schweinehaltung. Landwirtschaftsausstellung der DDR, Markkleeberg 1977, $39 \mathrm{p}$.

STARÝ, aj.: Jednotné biochemické metodiky zařazené do souboru metabolického testu. ÚSVÚ Praha, Pardubice 1979. 34 p.

THOMPSON, J. N. - ERDODY, P. - BRIEN, R. - MURRAY, T. K.: Fluorometric determination of vitamin A in human blood and liver. Biochem. Med., 5, 1971: 67-89.

THOMPSON, J. N. - ERDODY, P. - MAXWELL, W. B.: Simultaneous fluorometric determinations of vitamins $A$ and $E$ in human serum and plasma. Biochem. Med., 8, 1973: 403-414.

WIESNER, E.: Chronische Nitratbelastung bei Wiederkäuern. Mh. Vet. Med., 33, 1978: 834-835. 